\title{
A Study of the Minke Whale
}

\section{By Arthur G. Bourne}

Since 1939 Norwegian hunters of minke whales have been required by the government to keep detailed records of their catches. Arthur Bourne has recently studied these records for the FPS and has found a significant decline in the number of calves taken, which, together with other evidence, suggests a decrease in stocks. As a preliminary step to a study of the minke population the Norwegians started marking experiments in 1964 which are being continued. The minke whale has several names: Slijper calls it the lesser piked or minke; the Handbook of British Mammals the lesser rorqual or pike.

THE minke or pike whale Balaenoptera acutorostrata is the basis of a small whaling industry all along the Norwegian coast, westwards to Scotland, Shetland and the Faroes, and northwards to Bear Island, Spitsbergen and the Barents Sea. In the spring and early summer, after breeding, the minke whales migrate northwards. Their route is up the north-eastern Atlantic seaboard, to the west of Ireland, entering the North Sea from the north-they have never been observed to pass through the Straits of Dover-then moving up the west coast of Norway. At this stage the sexes are segregated; the pregnant females forming the vanguard are generally found closer inshore, sometimes penetrating up the fjords; the males tend to stay offshore in deeper water, and are never found in the fjords. The whales occur singly or in small groups of two or three, certainly as far as northern Norway. In the Arctic, off Spitsbergen, Bear Island and in the Barents Sea generally, they are found in large schools, probably due to the high concentration of food rather than to a genuine gregariousness. The migration route is reversed when the minke retreat before the Aretic winter.

The Norwegians started hunting the minke in the 1920's. The industry grew rapidly, and since the end of the second world war has been extended into the north Atlantic and the Arctic. In 1938 the Norwegian Government instituted a licensing system, requiring each vessel to be registered, and an act passed on June 16, 1939, laid down regulations for the industry. Today some 200 licences are issued annually. In 1950 a close season of three weeks in July was introduced, and since 1955 whaling in Arctic waters north of $70^{\circ} \mathrm{N}$ after June 30 has been forbidden. By international agreement the season in all other areas must not exceed six months; it opens on March 15 and closes on September 15. In addition the whalers are required by the 1939 Act to report their catches and provide details of each whale: the species, length in English feet, sex, date and position where caught, and, in the case of pregnant females, the statistics of foetuses. Between 1938 and 1958 inclusive, details of 53,786 minke whales were recorded; 


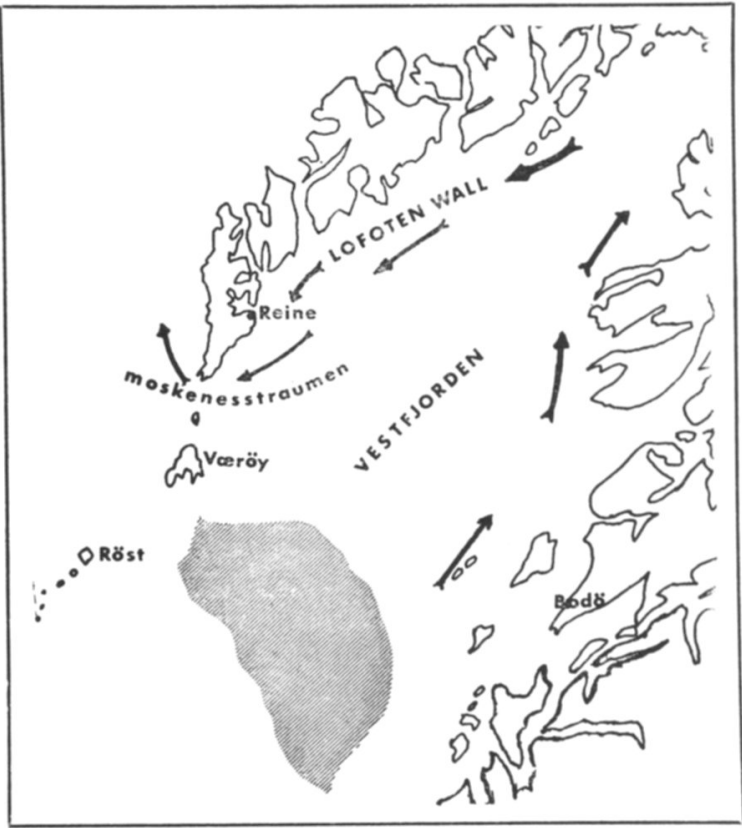

\author{
Map \\ showing the \\ route of \\ Minke Whales \\ into and out \\ of the \\ Vestfjorden \\ off Norway
}

52,990 of them were used in the studies on the minke whale populations carried out by Jonsgård and his colleagues, and of these just over 50 per cent. were males.

\title{
Signs of Over-Exploitation
}

The regulations have thus produced a rich harvest of statistical data, but they have not controlled the cropping of young whales and pregnant females, for there has been no limit to the size or the number of whales that may be taken by each boat-it would be difficult to enforce such regulations anyway-and today there are signs that the minke whale populations are being over-exploited. There has been a marked decrease in the numbers of small calves taken, in spite of the fact that the total catch had until recently increased each year; moreover, the percentage of mature animals in the annual catch has shown a marked increase, which also probably indicates that recruitment is falling. The industry is based on the production of meat for human consumption and for animal food; blubber for oil takes only a secondary place. That it is of economic importance can be judged from the fact that it employs some $\mathbf{8 0 0}$ men, and the value of the products, although liable to fluctuate, reaches three or four million kroner a season, the all-high peak being in 1949 with eight million kroner.

The boats used are small, 40-60 ft. long. With a three- to four-man crew they are able to keep at sea for several days. Their speed is up to seven knots, and the gun on the bows fires a normal claw harpoon 


\section{Lesser Rorqual or Minke Whale}

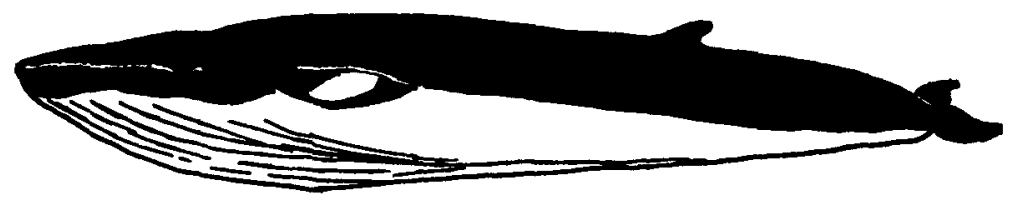

without an explosive shell. Several factors can tip the scale against the individual boat getting its whale: even in moderately choppy seas minke whales are difficult to locate and more so to shoot; prolonged dives enable the whale to take avoiding action, or at least to be lost sight of; and bad weather may cause the whaling to be called off for several days. Both the bottle-nosed Hyperoodon rostratus and killer whales Orcinus orca are also taken, but they form less than ten per cent. of the catch.

Decline in Lofoten Catch

The average catch has steadily increased from about five whales per boat to about eighteen. Up to the end of the war most whales were taken in the Lofoten area, but after 1946 the opening up of the fishery in the Arctic reduced the Lofoten catch to about 29 per cent. of the total. There was no decline in the actual catch in the Lofoten area, however, until recently when it became most marked-in 1959 only 524 whales were taken-and evident in other areas too. despite the increased size of the boats and improved equipment. Only the expansion of the whaling westwards and into the Arctic enabled the apparent increase in catch per boat to be kept up.

\section{Marking Experiments}

In order to study the populations of minke whales more closely, a marking programme was devised, and during the close season in July, 1964, an attempt made to mark some of the minke moving into the Vestfjorden. As shown on the map, the minke enter the large fjord, formed by the Lofoten wall and the Norwegian mainland, from south-east of Bodö, and then, finding themselves trapped at the northern end, turn south-west along the wall until they reach the strong current off Moskeness and are able to make their escape into the open waters of the Norwegian sea. This natural trap offers the Lofoten whalers a great opportunity, as do the whales that gather at the mouth of the fjord just south of Vaeröy and east of Röst to feed.

For the experiments a $40 \mathrm{ft}$. whaler Vesterheimen was hired. The markers used were six inches long, and consisted of a stainless steel tube with a ballistic soft metal head; the serial number and address of the State Institute for Whale Studies in Oslo was engraved on the tube. These were shot from a rifle on the gun platform, often under considerable difficulties due to the rolling and pitching of the boat. Several whales were successfully marked, which should not only enable 
studies on life histories to be made, but also, of more immediate importance, enable us to see whether the stocks of the Arctic are related to those found off Lofoten and western Norway. If they are this could have serious consequences for the industry. In any case it is essential to have this information to build up a picture of the whales' movements before conservation measures can be taken and a rational cropping programme devised.

The Norwegian Government provided a grant for the 1964 and 1965 experiments, but if this work is to be continued and extended further funds must be found. Future plans include the extension of the programme into the Arctic using two vessels, each equipped with two rifles and scientific staff, at a cost of $£ 1500-$-a small price to help ensure the continuance of a species.

\section{Summary}

In Norway the minke whale forms the basis of a not inconsiderable industry. There are regulations governing the conduct of the industry and providing a close season, but none to limit either the size of the whales that may be taken or the numbers. There are indications that the catches are only being maintained through greater efforts and improvements in equipment, and evidence that the stocks are being reduced through over-exploitation. The industry relies on the fact that the minke regularly migrate up the coasts of Norway and into the north Atlantic and Arctic. In order to study these movements more fully and to investigate the population structure, marking trials were started during the summer of 1964, proved successful and are to be continued.

\section{THE SOMALI WILD ASS}

NOT more than two very small herds of the Somali wild ass survive in Somalia, says Dr. E. Hufnagl, a member of the FPS in Tripoli, who has made intensive enquiries in the last five years, during three of which he was living in north-east Africa. Together the two herds number about ten to twelve animals; one herd is in the Modug, the other in the Migiurtinia region. Although they are effectively protected the chances of survival of such a small population are not great. In Ethiopia the position of the wild asses is more hopeful. Major Grimwood, during his survey in the spring of 1965 , found a thriving population of between 200 and 250 near Sardo. Plans were drawn up for a Game Reserve, and since the appointment of $\mathrm{Mr}$. John Blower as Senior Game Warden last year there are hopes that Ethiopia will protect this herd effectively.

\footnotetext{
A PAPERBACK reprint of a famous book on animals in zoos is $H$. A. Hediger's Wild Animals in Captivity, an outline of the biology of zoological gardens (Constable, 14s), first published in 1950 when the author was director of the Zoological Gardens at Basle.
} 